http://revped.ise.ro

Print ISSN 0034-8678; Online ISSN: 2559 - 639X

\title{
MODERN EDUCATIONAL REFORMS IN VOCATIONAL EDUCATION IN TURKEY
}

REFORME EDUCAȚIONALE MODERNE ÎN SISTEMUL EDUCAȚIONAL VOCAȚIONAL DIN TURCIA

\author{
Makhira H. MALYSHEVA \\ Journal of Pedagogy, 2018 (2), 57 - 67 \\ https://doi.org/10.26755/RevPed/2018.2/57
}

The online version of this article can be found at: http://revped.ise.ro/category/2018-en/

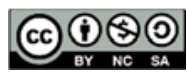

This work is licensed under the Creative Commons Attribution-NonCommercial-ShareAlike 4.0 International License. 94042, USA.

Published by:

\section{INSTITUTUL DE ȘTIINȚE ALE EDUCAȚIEI}

http://www.ise.ro/

Further information about Revista de Pedagogie - Journal of Pedagogy can be found at:

Editorial Policy: http://revped.ise.ro/editorial-policy/

Author Guidelines: http://revped.ise.ro/the-writer-guide-2/ 


\title{
MODERN EDUCATIONAL REFORMS IN THE SYSTEM OF VOCATIONAL EDUCATION IN TURKEY
}

\author{
Makhira H. Malysheva* \\ Institute for Vocational Education of the National Academy of \\ Pedagogical Sciences of Ukraine \\ Kiyv, Ukraine \\ m.h.malicheva@gmail.com
}

\begin{abstract}
The article covers modern educational reforms in Turkish vocational education and their impact on the quality of vocational education as well as vocational education development. The key factors, which predetermine educational reforms, were considered and their results were analysed. The advantages and disadvantages of such changes were justified. It was concluded Turkish experience in this field could be rather useful for foreign countries, which are on the way of enhancing the quality of their national vocational education.
\end{abstract}

Keywords: Educational reforms, Turkey, vocational education.

\section{Rezumat}

Articolul urmăreşte reforma educ ională pe zona educa iei voca ionale în Turcia, impactul şi dezvoltarea educa iei voca ionale. Au fost lua i în considerare factorii cheie care influen ează reforma educa ională şi au fost analizate rezultatele lor. Au fost prezentate avantajele şi dezavantajele unor astfel de schimbări. S-a concluzionat că experien a turcă $\hat{\imath}$ acest domeniu ar putea fi folositoare altor ări care urmăresc îmbunătă irea calită ii educa iei profesionale.

Cuvinte-cheie: Educa ie voca ională, reforma educa iei, Turcia.

* Postgraduate student of the Institute for Vocational Education of the National Academy of Pedagogical Sciences of Ukraine. 


\section{Introduction}

Nowadays, one can observe how the processes of globalization and integration into a single European space, the increasing value of international relations cause transformational changes in society, namely educational reforms in the system of vocational education, which should take into account international requirements and the best international practices.

Being a country that intends to compete and defend its social and economic position at the global market, Turkey started to carry out an educational reform and restructuring education system including vocational education and training. The purpose for such reforms was meeting the rapid changes in all aspects of life, ensuring modernization and adaptation to the socioeconomic needs and compliance the international requirements by the education system, including those that are of high priority in the European Union. The driving factor in the implementation of educational reforms in Turkey was the need for subjects of training to be ready for effective implementation of professional functions in a dynamic and changing life, which necessitates the acquisition of necessary qualifications with the further continuous upgrading of professional knowledge, abilities and skills of all members of society, regardless of their age, gender, welfare and social status.

Ukraine and Turkey share certain common problems in the field of vocational education. The labour market in Turkey develops very rapidly and requires the establishment of steady relations between its participants and educational institutions. The attempt to implement the latest innovations into production causes the need for closer cooperation with EU countries and the USA in the field of education and science. In addition, Turkey, like Ukraine, has faced the need to promote its education at the global and European levels in order to ensure its positive image and attractiveness in the world.

In this regard, theoretical analysis of the educational reforms implemented in Turkey over the last decade and their impact on development of vocational and continuing education are of great scientific interest. 


\section{Ukrainian and foreign scholars' views on vocational education}

Ukrainian and foreign scholars study the education systems in Turkey and their development under reforming. Having thoroughly explored the system of vocational education in Turkey in the 20th century the Ukrainian scholar, T. Desiatov (1998) outlined those challenging aspects that should be solved in the early 21 st century. Studying the development trends of the system of higher teacher education, S. Usmanova (2011) conducted comparative analysis of educational levels in Ukraine and Turkey. The scholar concluded that Ukrainian and Turkish higher education systems are characterized by the advantages of multi-level structure of higher education, namely, the implementation of a new education paradigm and the possibility of integration into the global educational space (Usmanova, 2009). Scientific researches by A. Gazizova and L. Gurie (2008) analyse the strategies for reforming the system of higher education in Turkey and the issues of teacher training in higher education institutions. The researchers state that the characteristic feature of higher education reforms in Turkey is the search for the optimal correspondence between Turkish traditional higher education and the new trends caused by the participation of the Muslim country in the Bologna process (Gurie \& Gazizova, 2008). F. Yakubov (2012) monitors and highlights achievements of Turkish universities in recent decades, namely, university autonomy was increased; their financial dependence on the state was reduced; academic freedom of teaching staff was promoted; the structure of universities internal management was improved; the European model of research activities was developed; the adaptation of universities to changing conditions was enhanced, etc. While analysing the national education organization in Turkey, S. Sapozhnikov (2011) reviews modern higher education system and indicates that Turkey's higher education management is centralized and carried out by the Ministry of National Education, which includes a central office as well as provincial and foreign representational offices. The main duties of the Ministry of National Education include: planning, monitoring and managing all educational services in different institutions; establishing formal and non-formal education institutions; organizing Turkish citizens' training abroad; developing and approving curricula; coordinating activities of official, private and public organizations; updating facilities in education institutions (Sapozhnikov, 2011). 
Having analysed researches by Turkish scholars (Ünal Başusta, Mustafa Yunus Eryaman, Sava Küce, Leslie David, Özelli, M. Tunç, Cem Tarhan, Berna Tezcan, Özgener Şevki, etc.), M. Chykalova (2011) describes how the leading universities in Turkey organize and support the education policy of vocational education and development of hospitality specialists under modern conditions of tourism education in the country. The scholar mentions that every year there are innovative approaches, systems and traditions, which depend on many factors of economic, political and social development of the country, thereby enhancing relevance of the study of modern educational reforms in Turkey that are being continually developed.

Certain Turkish researchers believe that vocational education is an important element, which allows personality to develop according to the changes in the field (Sari, 2007, p. 7). Vocational education aims to comprehensively develop the individual's capabilities, so that they may acquire the knowledge, abilities and skills, which are necessary for their further professional life (Hacioğlu, 1992, p. 91). Vocational education is the system of education and learning, which allow citizens to obtain a certain profession based on the knowledge, which are developed during the education process, organized in accordance with vocational requirements and specificity of the labour market (Bozok, 1992, p. 45). Vocational education is the process of developing physical, emotional, social and economic aspects of personality through providing knowledge, abilities and practical skills, which are necessary to obtain a profession (Aymankuy \& Aymankuy, 2002, p. 29). Thus, Turkish researchers understand vocational education as the organization of the education process and creation of optimal conditions for professional and personal development of vocational education students through mastering knowledge, abilities and practical skills in a particular profession.

So, researches by Ukrainian and foreign scholars prove their diversity in studying the strategies for improving higher education quality in Turkey. However, the current reforming process and changes in Turkish education systems do affect vocational schools, whose experience in modern development can be perspective and advisable while modernizing vocational education in Ukraine. 


\section{The aim of the study}

The aim of the study is to analyse modern educational reforms in the system of vocational education in Turkey and consider their impact on vocational education development.

\section{Reforming vocational education in Turkey}

The reforming of vocational education in Turkey is carried out by Ministry of National Education, which is responsible for general education management, comprehensively reforms all areas of VET and higher education. Presently, the national education structure in Turkey is regulated according to the Basic Law of National Education (1973), and its main types are formal and non-formal education. Formal education provides individuals of certain age with regular training based on the programmes designed for different purposes. Formal education is provided by preschool, primary, secondary and higher education institutions. Non-formal education involves short courses, social learning, and distance learning in public and private schools, vocational education centres, which are coordinated by Ministry of National Education.

Preschool education is optional for children under the age of 6; subsequently, they are to obtain primary and secondary education. Modernization of secondary education in Turkey began with the adoption of the Primary Education and Secondary Education Law in March 2012. It states that fouryear secondary education in the country can be of two types: general high secondary education (general high schools, Anatolian high schools, natural sciences high schools, social sciences high schools, fine arts and sports high school, teaching schools, multi-programme high schools) and vocational secondary education (technical and industrial vocational high schools, technical and industrial schools for girls, vocational schools of hotel management and tourism, business schools, medical schools, multidisciplinary schools). Consequently, the structure of modern secondary school in Turkey comprises education institutions called "vocational schools", which, in our opinion, are quite similar to Ukrainian high vocational schools. 
The system of vocational secondary education in Turkey includes two main aspects: theoretical aspect (training in vocational schools) and practical one (training in enterprises). Changes in the system of students' vocational training started long ago. The latest of them date back to 2001, when a law that determined the creation of new and strong links between vocational schools and enterprises (cooperations) of industry and trade was passed in Turkey. The vocational training policy in vocational schools is still carried out mainly under the Law on Apprenticeships and Vocational Training (1986), adopted by MoNE. This law is aimed at implementing vocational education, vocational guidance and training and contains requirements for the subjects of education in vocational schools and the conditions for their vocational training. In this context, it must be noted that in Turkey, vocational schools provide training for more than 130 professions; after finishing studies, graduates receive the qualification of a specialist and a technician. Thus, the system of vocational education in Turkey is aimed at performing innovative functions in the specialists' vocational training, since their relevance is confirmed by the experience of developed countries and the European Union.

It is well-known that the innovative concept of the Life-Long Learning Concept is the fusion of two logics within its framework, namely, the logic of education (the development of citizens' abilities) and the logic of production (an optimal use of human resources), aimed at uniting two systems, namely, the general education system and the vocational education one. Therefore, the strategies for continuing education development in Turkey complement formal, non-formal and informal education to create a flexible system of life-long learning.

Therefore, the today's system of vocational education in Turkey is aimed at providing future specialists with quality vocational training in order to ensure welfare of Turkish citizens, support and enhance economic, cultural and social development of national and social cohesion, so that Turkey may become a constructive, creative and outstanding partner of modern civilization. On the way to the European area, it is important to promote higher education in Turkey, which signed the Bologna Declaration in 2001. The country's higher education became stage-based after the European Credit Transfer System (ECTS) was introduced, and now graduates obtain academic diplomas recognized by the EU. 
Compliance with the principles of consecutive education is reflected in the National Qualifications Framework of Turkey, which is in line with the European Qualifications Framework. The national qualification framework in Turkey consists of 8 reference levels and is the basis for qualifications, which are aimed at adhering to the principles of competences adopted by the European Union and promoting the achievement of the programme objectives in primary, secondary and tertiary education, including private education, as well as vocational education and training programmes, which belongs to the field of formal, non-formal and informal education. Each level of the National Qualifications Framework in Turkey includes combination of specific knowledge, skills and competences. These levels cover a wide range: from elementary level (level 1) to the highest level of education (level 8). Each level of education encompasses different scope complexity of expected knowledge, skills and competences.

Focusing on the priorities of the Copenhagen Declaration (2002), identified for the candidate countries and member states of the European Free Trade Association and European Economic Area, as well as social partners in strengthening VET cooperation, Turkey has been implementing initiatives aimed at the citizens' needs over the past decades. Thus, it ensures achieving strategic goals of joint activities, namely, improving quality and effectiveness of VET systems in the EU, facilitating access to education for all citizens, providing openness to the world (European Commission).

Based on a new global need for improving quality of Turkish education up to the level in European or other developed countries, guided by the national resolutions outlined in plans for the country's development, governmental programmes and the Declaration for General Education Goals, Turkey has been approximating quality of educational services to social and economic demands and principles of lifelong learning (LLL) for decades. It considers LLL to be a strategic initiative and the most flexible system that can provide optimal conditions for continuing expansion of knowledge; ensures an organic link between various kinds of education or vocational experience and qualification; enables to adequately resolve issues related to the gap that exists between demand and offer in the labour market and adapt Turkish vocational education to European standards. 
The Continuing Education Concept is the basis for Turkey's strategic development programmes, including a long-term strategy (Long Term Strategy (2001-2023) aimed at increasing Turkey's stability and competitiveness on global scale; society informatisation; completing the processes of education systems "equalization" up to the level required for membership in the European Union, that is the completion of education systems" "approaching" to the level of compliance with qualification levels adopted in the European space.

In September 2011, the changes in the MoNE led to creating a separate group of specialists in its structure, whose activities include solving those tasks related to the LLL concept implementation in Turkey, namely:

- Developing a policy of education and training integration required for LLL, with the exception of compulsory education and ensuring its implementation, monitoring and evaluation;

- Ensuring access to non-formal education and openness of educational services;

- Providing those citizens who did not obtain formal education, dropped out or did not finish formal education at a certain stage and require further training with general or vocational education through non-formal education;

- Preparing and presenting non-formal education facilities for education and training outsourcing, as well as their agreement with the Education Council;

- Providing services related to non-formal education in private education institutions;

- Providing all population groups (students, retirees) with access to comprehensive and vocational education under the Law on Apprenticeship and Vocational Training (1986).

Thus, the LLL concept implementation required that Turkish government develop and approve legislative and regulatory documents (the Law on Vocational Qualification Authority, 2006; the Non-Formal Education Institutions Decree, 2006; the Primary Education and Education Law, 2012, etc.), aimed at realizing core principles (everyone should be able to acquire new basic skills; significant investments should be made in human resources; innovative teaching and learning methods should be promoted; the level of educational qualifications should be assessed; mentoring and counselling should be developed; the education system should be at most approximated 
to national reality etc.) of a Memorandum on Lifelong Learning in Europe (Lisbon, 2000).

\section{Conclusions}

The above-mentioned reforms related to the LLL concept implementation in Turkey are extremely important for the country's innovative progress in the European area. However, there still exists a range of issues relevant for modern reforming processes in vocational education, namely, coordination and compliance of vocational training outcomes with the labour market needs based on its quantitative and qualitative analysis; development of standards in vocational education and corresponding educational standards; design of curricula and training programmes based on vocational skills and modular technologies; strengthening of social relationships with employers and their involvement into active participation in the process of improving vocational education; enhancement of VET teachers and managers' vocational skills; adjustment of VET quality to the European qualifications framework; implementation of the LLL concept; establishment and functioning of vocational qualification bodies required to increase awareness of vocational education prestige and create vocational information systems, etc.

So, particularly significant changes must be made in the system of vocational education and training; its key elements are the following:

- Establishing the links between the system of vocational education and the labour market;

- Developing vocational standards and prospective training standards;

- Designing vocational education curricula taking into account competencyand module-based approaches and learning outcomes;

- Strengthening social partnership in vocational education;

- Enhancing qualification of teaching and managerial staff engaged in vocational training area;

- Meeting the requirements of the European Qualifications Framework;

- Justifying and implementing the concept of life-long learning;

- Supporting the Vocational Qualifications Agency;

- Promoting vocational education value; raising awareness of vocational education; 
- Developing vocational information systems.

Such guidelines in the modernization process of Turkish education as a whole contribute to developing a modern and flexible system of vocational education. Therefore, the implementation of Turkey's experience in vocational education in different countries, in particular in Ukraine, will facilitate the creation of new opportunities for developing modern high-quality vocational education.

\section{References}

- Aymankuy, Y., \& Aymankuy, Ş. (2002). Önlisans ve Lisans Düzeyindeki Turizm Ĕgitimi Veren Yüksekögretim Kurumlarının Bulundukları Yerlerin Analizi ve Turizm Ĕ̈itimi çin Öneri Bir Model. Turizm Eğitimi Konferans-Workshop, 1113 Aralık (ss. 29-41). Ankara: Turizm Bakanlığı Turizm Eğitimi Genel Müdürlüğü.

- Bozok, D. (1992). Turizm şletmelerinde Profesyonel Yönetici ve Eğitimi Sorunları. Türkiye Kalkınma Bankası Turizm Yıllı̆̆, 7, 40-53.

- Chykalova, M. M. (2014) Pedagogical conditions for retraining and advanced training for tourism (taking into account the experience of Turkey). Electronic Professional (Pedagogical) Edition "Public education”, 2 (22). Retrieved from http://www.narodnaosvita.kiev.ua.

- Desiatov, T. M. (1998). The system of vocational education in Turkey. (Abstract of $\mathrm{PhD}$ thesis). The Institute for Pedagogy and Psychology of Professional Education of the Academy of Pedagogical Sciences of Ukraine, Kyiv.

- Education and Culture DG. (2013). European values in vocational education. EVive. Lifelong Learning Programme. Retrieved from http://www.aubg.edu/ documents/375.

- European Commission and Ministers of Professional Education of European countries. (2002). Declaration of the European Ministers of Vocational Education and Training, and the European Commission, convened in Copenhagen on 29 and 30 November 2002, on enhanced European cooperation in vocational education and training. Retrieved from https:// europass.cedefop.europa.eu/sites/default/files/copenhagen-en.pdf.

- Gurie, L., \& Gazizova, A. (2008) Problems of training teachers of universities in Turkey. Higher Education in Russia, 10, 115-120.

- Hacıoğlu, N. (1992). Dış Tanıtım ve Örgütleme Modeli. Ankara: Türkiye Kalkınma Bankası A.Ş. Yayınları.

- Sapozhnikov, S. V. (2011). The system of higher education of the Republic of Turkey under contemporary conditions. Bulletin of Dnipro Alfred Nobel University of Economics and Law. Series: Pedagogy and Psychology, 1, 41-45. 
- Sari, H. (2007). Ortaöğretim Düzeyinde Mesleki Turizm Ĕ̆itimi Alan Öğrencilerin Staj Sürecine Adaptasyonu Üzerinde Bir Araştırma. Ankara: Gazi Üniversitesi Eğitim Bilimleri Enstituis.

- Usmanova S. M. (2009) Comparative analysis of higher education levels in Ukraine and Turkey. Problems of Modern Pedagogical Education. Series: Pedagogy and Psychology, 21, 226-231.

- Usmanova, S. M. (2011). Trends in higher teacher education in the Republic of Turkey. (Abstract of PhD thesis). Crimean University of Humanities, Yalta.

- Yakubov, F. Ya. (2012). New trends in the system of higher education in Turkey. Professional Education: Issues and Prospects, 3, 3-5.

The online version of this article can be found at: http://revped.ise.ro/category/2018-en/

\section{$( c c ) \longdiv { B r - n e - 3 A }$}

This work is licensed under the Creative Commons Attribution-NonCommercial-ShareAlike 4.0 International License.

To view a copy of this license, visithttp://creativecommons.org/licenses/by-ncsa/4.0/ or send a letter to Creative Commons, $P O$ Box 1866, Mountain View, CA 94042, USA.
Versiunea online a acestui articol poate fi găsită la:http://revped.ise.ro/category/2018-ro/

\section{(cc) $\mathrm{BY}-\mathrm{NC}-\mathrm{SA}$}

Această lucrare este licen iată sub Creative Commons Attribution-NonCommercial-ShareAlike 4.0 International License.

Pentru a vedea o copie a acestei licen e, vizita $i$ http://creativecommons.org/licenses/by-nc-sa/4.0/ sau trimite i o scrisoare către Creative Commons, PO Box 1866, Mountain View, CA 94042, SUA. 